\title{
Volume and velocity changes at Mittivakkat Gletscher, southeast Greenland
}

\author{
Sebastian H. MERNILD, ${ }^{1,2}$ Niels T. KNUDSEN, ${ }^{3}$ Matthew J. HOFFMAN, ${ }^{4}$ \\ Jacob C. YDE, ${ }^{5}$ Edward HANNA, ${ }^{6}$ William H. LIPSCOMB, ${ }^{4}$ Jeppe K. MALMROS, ${ }^{2}$ \\ Robert S. FAUSTO ${ }^{7}$ \\ ${ }^{1}$ Climate, Ocean, and Sea Ice Modeling Group, Computational Physics and Methods, Los Alamos National Laboratory, \\ Los Alamos, NM, USA \\ ${ }^{2}$ Glaciology and Climate Change Laboratory, Center for Scientific Studies/Centro de Estudios Científicos (CECS), \\ Valdivia, Chile \\ E-mail: mernild@cecs.cl \\ ${ }^{3}$ Department of Geoscience, Aarhus University, Aarhus, Denmark \\ ${ }^{4}$ Climate, Ocean, and Sea Ice Modeling Group, Fluid Dynamics and Solid Mechanics, Los Alamos National Laboratory, \\ Los Alamos, NM, USA \\ ${ }^{5}$ Sogn og Fjordane University College, Sogndal, Norway \\ ${ }^{6}$ Department of Geography, University of Sheffield, Sheffield, UK \\ ${ }^{7}$ Geological Survey of Denmark and Greenland, Copenhagen, Denmark
}

\begin{abstract}
We document changes for Mittivakkat Gletscher, the peripheral glacier in Greenland with the longest field-based observed mass-balance and surface velocity time series. Between 1986 and 2011, this glacier changed by $-15 \%$ in mean ice thickness and $-30 \%$ in volume. We attribute these changes to summer warming and lower winter snow accumulation. Vertical strain compensated for $\sim 60 \%$ of the elevation change due to surface mass balance (SMB) in the lower part, and $\sim 25 \%$ in the upper part. The annual mean ice surface velocity changed by $-30 \%$, which can be fully explained by the dynamic effect of ice thinning, within uncertainty. Mittivakkat Gletscher summer surface velocities were on average $50-60 \%$ above winter background values, and up to $160 \%$ higher during peak velocity events. Peak velocity events were accompanied by uplift of a few centimeters.
\end{abstract}

\section{INTRODUCTION}

In recent decades, glaciers have thinned and receded in many regions of the world (Oerlemans and others, 2007; Cogley, 2012; Leclercq and Oerlemans, 2012). The contribution to sea-level rise due to mass loss from glaciers peripheral to the Greenland and Antarctic ice sheets is comparable to that from the ice sheets themselves and has increased in recent decades (Kaser and others, 2006; Meier and others, 2007; Cogley, 2012). The thousands of glaciers located peripherally to (and disconnected from) the Greenland ice sheet cover an area of $\sim 89300 \pm 2800 \mathrm{~km}^{2}$ (Rastner and others, 2012), compared with $\sim 1.7 \times 10^{6} \mathrm{~km}^{2}$ for the conterminous ice sheet (Kargel and others, 2012).

Our knowledge of the morphological characteristics, ice dynamics and climate sensitivity of these glaciers is limited (Marzeion and others, 2012). Glacier mass-balance studies often exclude the Greenland peripheral glacier contribution to sea-level rise (e.g. Jacob and others, 2012), even though Yde and Knudsen (2007), Bjørk and others (2012), Kargel and others (2012) and Mernild and others (2012) have documented substantial glacier area recession on Disko Island $\left(69-70^{\circ} \mathrm{N}\right.$; West Greenland) and in southeast $\left(65^{\circ} \mathrm{N}\right)$ and East Greenland $\left(68-72^{\circ} \mathrm{N}\right)$. Not only is the glacier area decreasing, but also the annual surface melt extent and the amount of surface melting and freshwater runoff from peripheral glaciers have increased during the past several decades (e.g. Mernild and Hasholt, 2006; Kargel and others, 2012). This trend agrees with observations and modeling of runoff from the Greenland ice sheet (Hanna and others, 2008, 2012a; Mernild and Hasholt, 2009; Mernild and others, 2010; Mernild and Liston, 2012), where increased surface melting influences glacier dynamics through changes in subglacial hydrology (e.g. Van der Wal and others, 2008; Sundal and others, 2011).

Mittivakkat Gletscher (henceforth MG; Fig. 1), located in the Ammassalik region, is Greenland's only peripheral glacier for which there exist surface mass-balance (SMB) records (since 1995), surface velocity measurements (since 1995), aerial photographs and satellite margin and area observations (since 1900) (Mernild and others, 2011a, 2012; Bjørk and others, 2012). This study analyzes spatial changes in MG's SMB (winter, summer and annual net mass balances) and quantifies the decrease in ice thickness, volume and surface velocity during a 25 year period of climate warming (1986-2011). These new results of ice thickness, volume and surface velocity changes supplement a previous study of MG by Mernild and others (2011a), where the focus was on the relations between frontal glacier recession and recession rates, annual net mass-balance and accumulation-area ratio (AAR) conditions relative to out-ofbalance conditions and the committed area and ice volume loss even in the absence of further climate changes.

\section{STUDY AREA}

Mittivakkat Gletscher $\left(65^{\circ} 42^{\prime} \mathrm{N}, 37^{\circ} 48^{\prime} \mathrm{W} ; 26.2 \mathrm{~km}^{2}\right)$ is located in what is considered the Low Arctic (Born and Böcher, 2001), with a local mean annual air temperature of $-2.2^{\circ} \mathrm{C}$ (1993-2011) (Hanna and others 2012b), and mean annual precipitation in the range $1400-1800 \mathrm{~mm}$ w.e. $\mathrm{a}^{-1}$ 
(1998-2006) at Tasiilaq (from the Danish Meteorological Institute (DMI) station located $\sim 15 \mathrm{~km}$ southeast of MG) (Mernild and others, 2008a). The glacier is temperate (i.e. ice at the pressure-melting point), with seasonal temperature excursions in the upper few meters (Knudsen and Hasholt, 1999). Since its maximum extent during the Little Ice Age, MG has undergone almost continuous retreat (Knudsen and Hasholt, 1999; Knudsen and others, 2008; Mernild and others, 2011a). During 1986-2011 the glacier area changed by $-18 \%$, from $31.6 \mathrm{~km}^{2}$ (1986) to $29.5 \mathrm{~km}^{2}$ (1999) to $26.2 \mathrm{~km}^{2}$ (2011) (Mernild and others, 2012), and the mean surface slope changed from $0.095 \mathrm{~m} \mathrm{~m}^{-1} \quad\left(=5.4^{\circ}\right)$ to $0.104 \mathrm{~m} \mathrm{~m}^{-1}\left(5.9^{\circ}\right)$. The area change of MG follows the overall trend of the Ammassalik region, where glaciers on average changed by $-27 \pm 24 \%$ during this period (Mernild and others, 2012).

For MG the annual SMB has been observed for 16 years since 1995/96, and the winter and summer balances for 10 of the last 12 years. The mean annual net mass balance is $-0.97 \pm 0.75$ mw.e. $a^{-1}(1995 / 96-2010 / 11)$, with a mean winter balance of $1.18 \pm 0.19 \mathrm{mw}$.e. $\mathrm{a}^{-1}$ and a mean summer balance of $-1.94 \pm 0.38$ m w.e. $a^{-1}$ (1995/96-2007/ 08) (Mernild and others 2013). The annual SMB has changed on average by -0.09 m w.e. $\mathrm{a}^{-2}\left(r^{2}=0.36 ; p<0.01\right.$, significant; where $r^{2}$ is the explained variance and $p$ is level of significance; the term 'significant' is only used where the relationship is statistically significant at the $10 \%$ level or better, based on a linear regression $t$-test). The explained variance in the annual winter and summer balances was $r^{2}=0.34 ; p<0.05$ and $r^{2}=0.01 ; p>0.25$, respectively. Winter and summer balances were not observed during several years in the later part of the record with highly negative annual SMB. The net balance in 2010/11 was a record setting, $-2.45 \mathrm{~m}$ w.e., about two standard deviations below the mean and $0.29 \mathrm{~m}$ w.e. more negative than the previous observed record low mass balance in 2009/10 (Mernild and others, 2011b).

Since 1995 the equilibrium-line altitude (ELA) has risen from $\sim 500 \mathrm{~m}$ a.s.l. to $750 \mathrm{~m}$ a.s.l. (Mernild and others, 2011a). For six years during this time frame the mass balance was negative for the entire glacier: 1997/98, 2000/01, 2004/05, 2006/07, 2009/10 and 2010/11. The average AAR is currently $\sim 0.15$.

\section{DATA AND METHODS}

\section{Thickness and volume}

In 1994 the MG surface elevation, bed topography and ice thickness were estimated based on monopulse radio-echo soundings (Knudsen and Hasholt, 1999). The mean MG ice thickness $(115 \mathrm{~m})$ was derived from measurements at 450 positions, spaced $\sim 100 \mathrm{~m}$ apart along profiles running across the glacier, and $\sim 300 \mathrm{~m}$ apart along the flowline with a vertical spacing of $50 \mathrm{~m}$ (two such profiles are illustrated in Fig. 2). The error in measured ice thickness was estimated to be less than $\pm 5 \mathrm{~m}$ (Knudsen and Hasholt, 1999), giving a relative uncertainty of $<5 \%$ for the mean 1994 ice thickness (115 m).

In 1995 a glacier observation program was initiated to measure MG's annual SMB and to map changes in ice thickness. A network of stakes (Fig. 1) was used to measure summer ablation (Fig. 3) based on the direct glaciological method (Østrem and Brugman, 1991; Mernild and others, 2011a). The vertical accuracy of observed annual stake

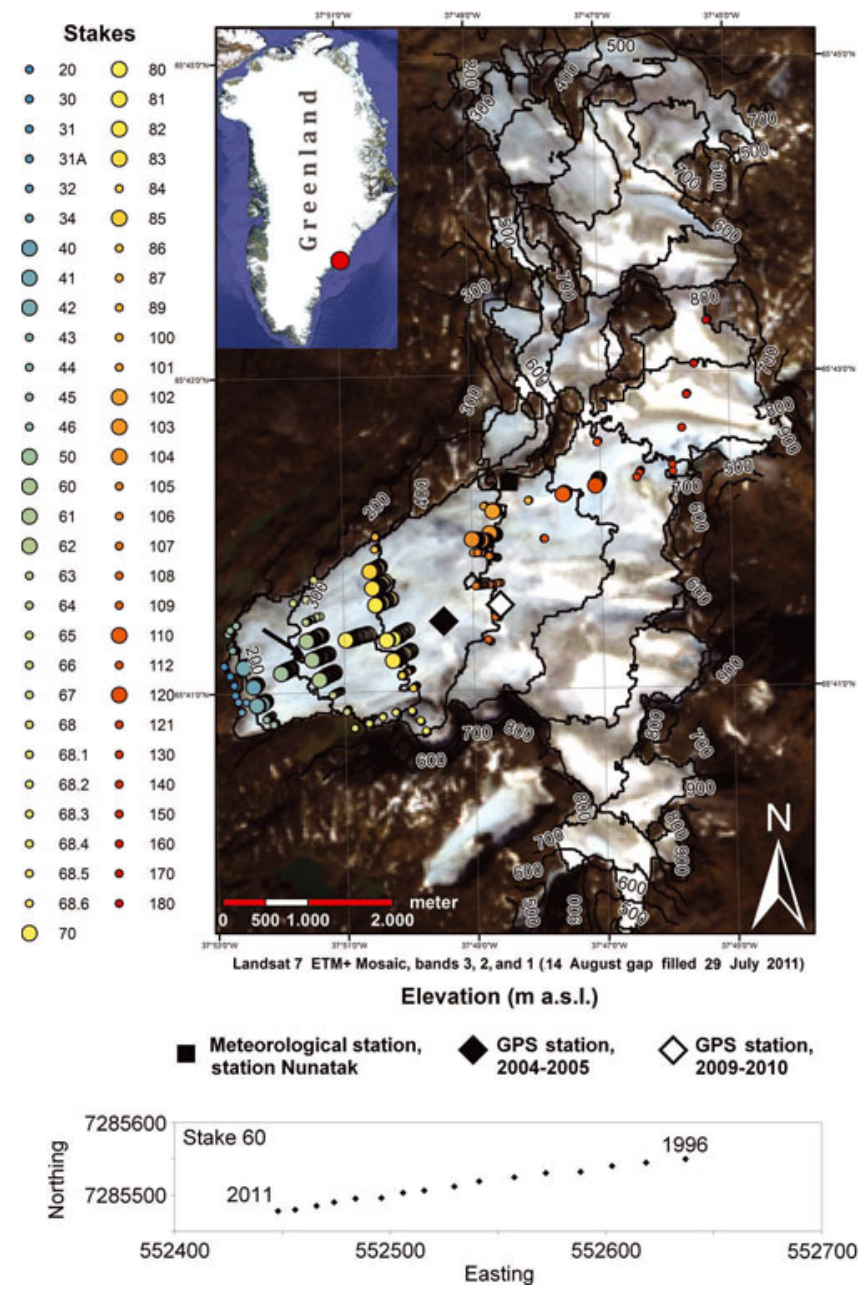

Fig. 1. Mittivakkat Gletscher $\left(26.2 \mathrm{~km}^{2} ; 65^{\circ} 41^{\prime} \mathrm{N}, 37^{\circ} 48^{\prime} \mathrm{W}\right)$ including topographic map (100 m contour interval), and circles illustrating the stake locations for the glacier observation program, 1995-2011. The stake colors on the glacier surface correspond to the stake numbers illustrated to the left, where the low numbers correspond to the stakes at the low-elevation part of the glacier, and the converse. The 18 stakes $(40,41,42,50,60,61,62,70,80,81$, $82,83,85,102,103,104,110$ and 120) measured continuously throughout the period are highlighted in bold. Due to a high density of crevasses in the southeastern part of the glacier, no stakes were located there. The meteorological station at the nunatak is shown by a black square, and the GPS station on the glacier by black and white diamonds. The inset indicates the location of MG in southeast Greenland. Below, an example of an annual time series (19962011) of stake locations is shown for stake 60, denoted by a black arrow on the map (source: Landsat 7 Enhanced Thematic Mapper Plus (ETM+) Mosaic, 1 August 2009 and 14 August 2011).

mass-balance measurements has been estimated to be within $5 \mathrm{~cm}$, or $< \pm 10 \%$ (Østrem and Stanley, 1969). Measurements were obtained at 59 stakes covering $16.3 \mathrm{~km}^{2}$ of MG, excluding the crevassed area in the southeastern part of the glacier (this omission is not likely to bias the results, since the surface of the crevassed area follows the general hypsometric distribution in the upper part of MG (Mernild and others, 2006, 2008b)). Since its establishment, the stake network has moved slowly downglacier by $50-275 \mathrm{~m}$ (based on calculations, this movement has an insignificant impact on estimates of the mean annual surface velocity). The winter balance was calculated as the difference between the net annual balance and the summer 

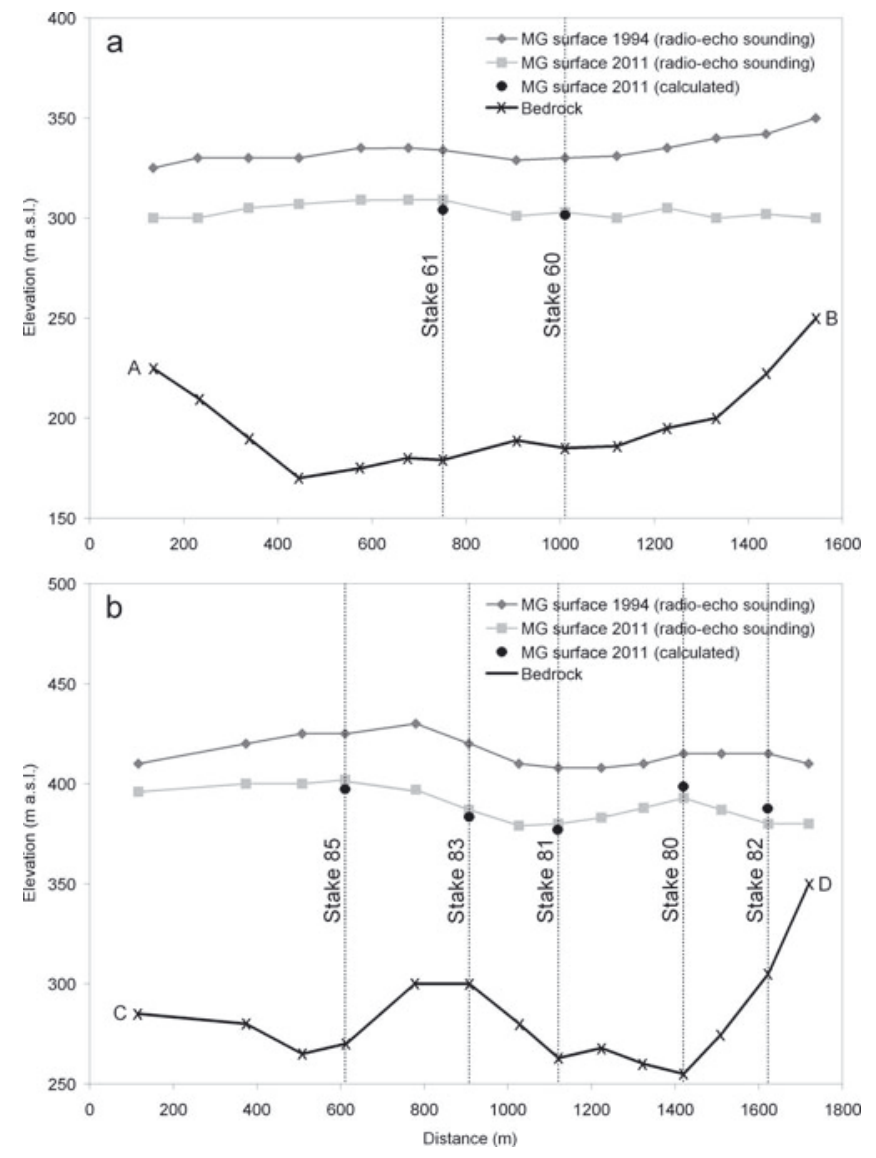

Fig. 2. A comparison between the 2011 calculated mean MG thickness and the 2011 and 1994 monopulse radio-echo sounding estimated mean thicknesses at two cross-section locations in the ablation area: (a) at $\sim 300 \mathrm{~m}$ a.s.l.; (b) at $\sim 400 \mathrm{~m}$ a.s.l. Approximate locations of the cross sections are shown in Figure 7c.

balance. The mass-balance observations are accurate within $\pm 15 \%$ for the entire MG (Fig. 3) (Knudsen and Hasholt, 2004), which is within the uncertainty range suggested by Cogley and Adams (1998) for these methods.

The MG ice volume was calculated for 1986, 1999 and 2011 and based on the satellite-derived glacier extent (from Landsat imagery) multiplied by the mean ice thickness (Mernild and others, 2012). The mean ice thicknesses for 1999 and 2011 were calculated from the observed 1994 mean thickness and the cumulative observed mass balance. To assess the accuracy of the calculations, we compared the 2011 calculated MG thickness against thickness measured in 2011 by monopulse radio-echo sounding along two crosssection profiles (both located in the ablation zone) (Fig. 2). The mean difference in ice thickness between the calculations and radio-echo soundings was on average $2 \mathrm{~m}$ (seven stakes, root mean square (rms) $=3 \mathrm{~m}$ ) (Fig. 2).

The 1986 mean ice thickness was estimated by adding the cumulative mass balance during 1986-94, based on modeled MG annual mass-balance data from Mernild and others (2008c), to the 1994 mean thickness (Fig. 4). The calculated MG annual mass balance was compared against observed mass balance for a control period 1995/96 to 2003/04, indicating an $r^{2}$ value of 0.71 (significant, $p<0.01$ ) and a difference less than $0.01 \mathrm{~m}$ between observed and calculated mass-balance values. The 1986-94 calculation method was extended back to 1981, at which point the mean calculated surface elevation was compared to a 1981 map
( $1: 20000)$ of digitized mean surface topography (Knudsen and Hasholt, 1999), indicating an average difference of 2-4 $\mathrm{m}(\mathrm{rms}=3 \mathrm{~m})$ (not shown).

The MG surface slope was calculated for both 1996 and 2011 for the longitudinal profile along stakes 31, 40, 50, 60, 70, 80, 107, 110, 120, 130 and 140 (Figs 1 and 5).

\section{Surface ice velocity and thickness changes}

Each stake position (Fig. 1) was measured annually, varying from 47 stakes in 1998 and 2001 to 18 stakes for the years 2008-11. Eighteen stakes were measured continuously throughout the period 1995/96-2010/11. Before 2004, the horizontal stake positions were measured by topographic surveys using a theodolite (Kern) with an Electro-optical Distance Meter, having a horizontal uncertainty of less than $\pm 1 \mathrm{~m}$. After 2004, stake position was based on a portable single-frequency GPS (Garmin GPS $12 \mathrm{XL}$ ) with a relative horizontal uncertainty (std dev.) of about $\pm 2-3 \mathrm{~m}$ (similar to a relative uncertainty of approximately $\pm 10 \%$ for maximum annual velocity, and $\pm 25 \%$ for mean velocity). The horizontal $\pm 2-3 \mathrm{~m}$ value is based on long time repeated fixed station measurements with the same instrument during several years. The annual stake positions were used to calculate the spatial mean surface velocity field.

Also, a continuous ice surface velocity time series was obtained from a dual-frequency GPS receiver (Javad Laxon GGD160T, operated by the Geological Survey of Denmark and Greenland) positioned near the center of MG (Fig. 1). This time series was used to determine the seasonal variability in ice surface velocity. However, we have access to data only from May 2004 through July 2005 (when the GPS receiver was located at elevations from 462 to 455 ma.s.l.) and from March 2009 through August 2010 (513-509 ma.s.l.). The horizontal and vertical uncertainties in the GPS time series were on average around 3 and $6 \mathrm{~mm}$, respectively.

Thickness changes, $\mathrm{d} h / \mathrm{d} t$, at a point on the glacier are a combination of SMB and vertical strain and can be described by continuity (Cuffey and Patterson, 2010) approximately as

$$
\mathrm{d} h / \mathrm{d} t=b-u_{\mathrm{s}} \tan \alpha+w_{\mathrm{s}}
$$

where $b$ is the $\mathrm{SMB}, u_{\mathrm{s}}$ is the horizontal surface velocity, $\alpha$ is the surface slope and $w_{\mathrm{s}}$ is the vertical velocity of a fixed point on the glacier (e.g. the top of a stake). However, our surveys measured the position of the ice surface at each stake, so our observed vertical velocity includes the SMB. Thus, we calculate thickness changes as

$$
\mathrm{d} h / \mathrm{d} t=w_{\mathrm{obs}}-u_{\mathrm{s}} \tan \alpha
$$

where $w_{\text {obs }}$ is the observed vertical velocity measured as the height difference between two successive surveys of the ice surface elevation at the position of a stake. We separate the component of thickness change due to vertical strain rate (emergence velocity, $w_{\mathrm{e}}$ ) as

$$
w_{\mathrm{e}}=\mathrm{d} h / \mathrm{d} t-b
$$

To assess how much of the deceleration in surface velocity can be explained by changes in thickness, the theoretical surface velocity due to deformation at the beginning and end of the study period was calculated using the shallow ice approximation (SIA; Hutter 1983):

$$
v_{\text {sia }}=1 /(2 A)(\rho g \mathrm{~d} s / \mathrm{d} x)^{3} H^{4}
$$

where $A$ is the flow law rate factor, taken as 


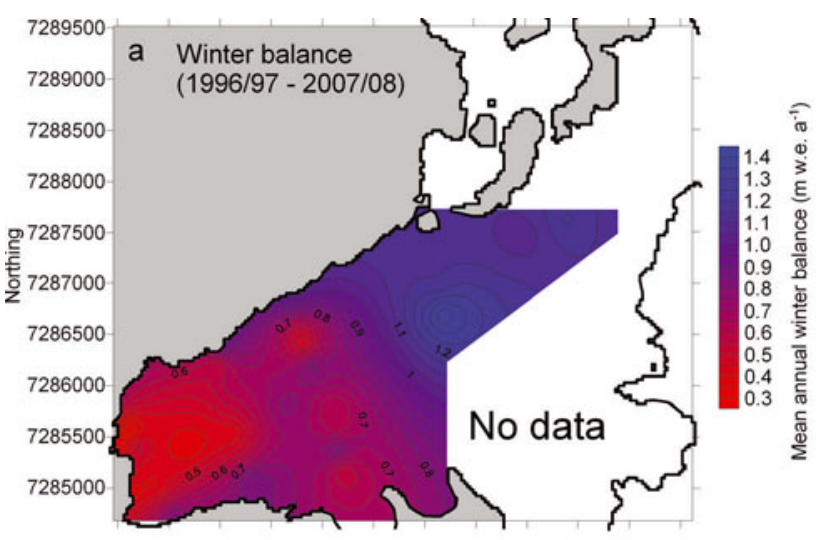

Annual change in net winter balance (1996/97 - 2007/08)

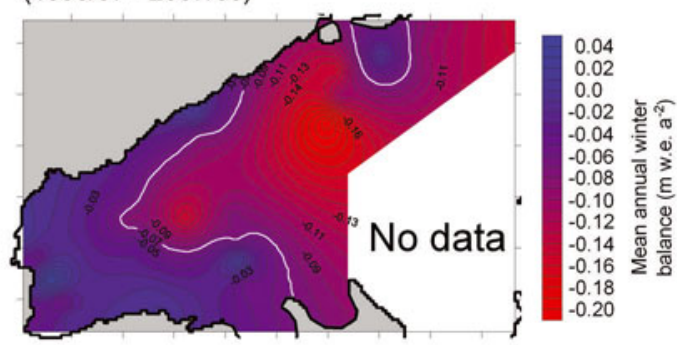

Annual change in

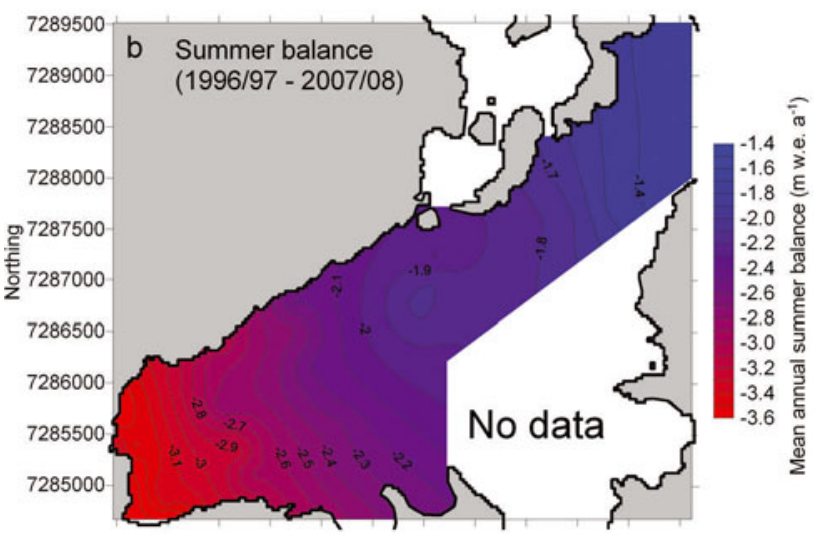

Annual change in net summer balance (1996/97 - 2007/08)
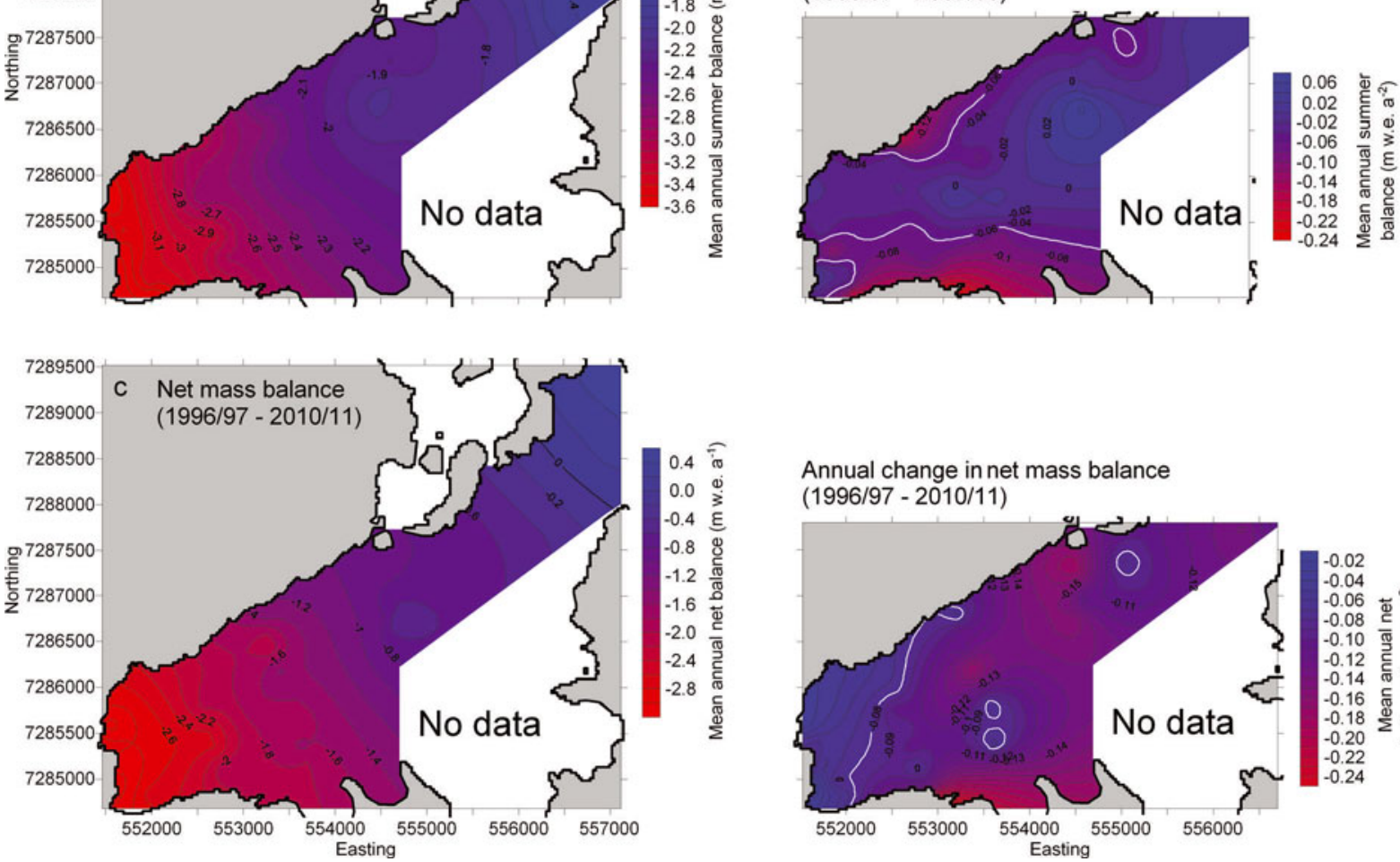

Annual change in net mass balance $(1996 / 97-2010 / 11)$

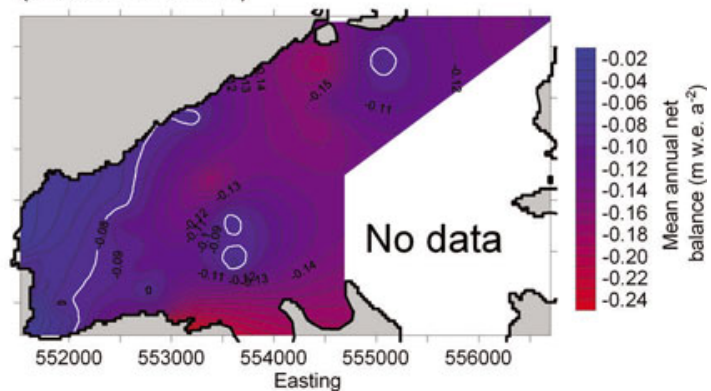

Fig. 3. Annual mass-balance distributions and changes at MG: (a) mean winter mass balance and annual change (blue-red shades); (b) mean summer mass balance and annual change; and (c) net annual mass balance and annual change for 1996/97 through 2010/11. The white bold lines (in the right-side panels) indicate the margin for significant annual trends in winter, summer and net mass balances, where values below are significant. The white area has no data, and the margin is based on Landsat 7 ETM+ Mosaic imagery, 1 August 2009 and 14 August 2011.

$2.1 \times 10^{-16} \mathrm{a}^{-1} \mathrm{~Pa}^{-3}$ for isothermal ice at $0^{\circ} \mathrm{C}$ (Cuffey and Paterson, 2010), $\rho$ is the density of ice taken as $900 \mathrm{~kg} \mathrm{~m}^{-3}, g$ is acceleration due to gravity, $9.81 \mathrm{~m} \mathrm{~s}^{-2}, \mathrm{~d} S / \mathrm{d} x$ is the surface slope and $H$ is the ice thickness. We apply Eqn (4) within the ablation area along the longitudinal profile from stake 31 through stake 80, performing the calculation midway between stake locations, based on the values of thickness, slope and observed velocity averaged between the two adjacent stake locations. This provides a flowline average over 3-5 ice thicknesses, which compensates somewhat for the fact that the SIA ignores longitudinal and lateral stresses that may be important for a mountain glacier. A shape factor is not used because MG is wide relative to its depth (half-width/thickness $\approx 10$ ).

\section{RESULTS AND DISCUSSION}

\section{Spatial surface mass-balance and thickness changes}

Figure 3 illustrates the mean spatial variations in winter, summer and annual net mass balances. The mean winter balance shows less accumulation at low elevations $\left(0.3 \mathrm{mw}\right.$.e. $\left.\mathrm{a}^{-1}\right)$ than at higher elevations (>1.4 $\mathrm{m}$ w.e. $\left.\mathrm{a}^{-1}\right)$ (Fig. 3a), with a mean orographic gradient of $\sim 0.2 \mathrm{~m} \mathrm{w.e.}^{-1}$ per $100 \mathrm{~m}$ increase in elevation (1995/96-2007/08). Figure 3a also illustrates the spatial distribution of the annual change in winter balance, showing that the terminus, the marginal areas at high elevations, and areas near mountain ridges had the smallest decrease, while other areas had an increasing winter balance $\left(0.04 \mathrm{~m}\right.$ w.e. $\left.\mathrm{a}^{-2}\right)$. The 


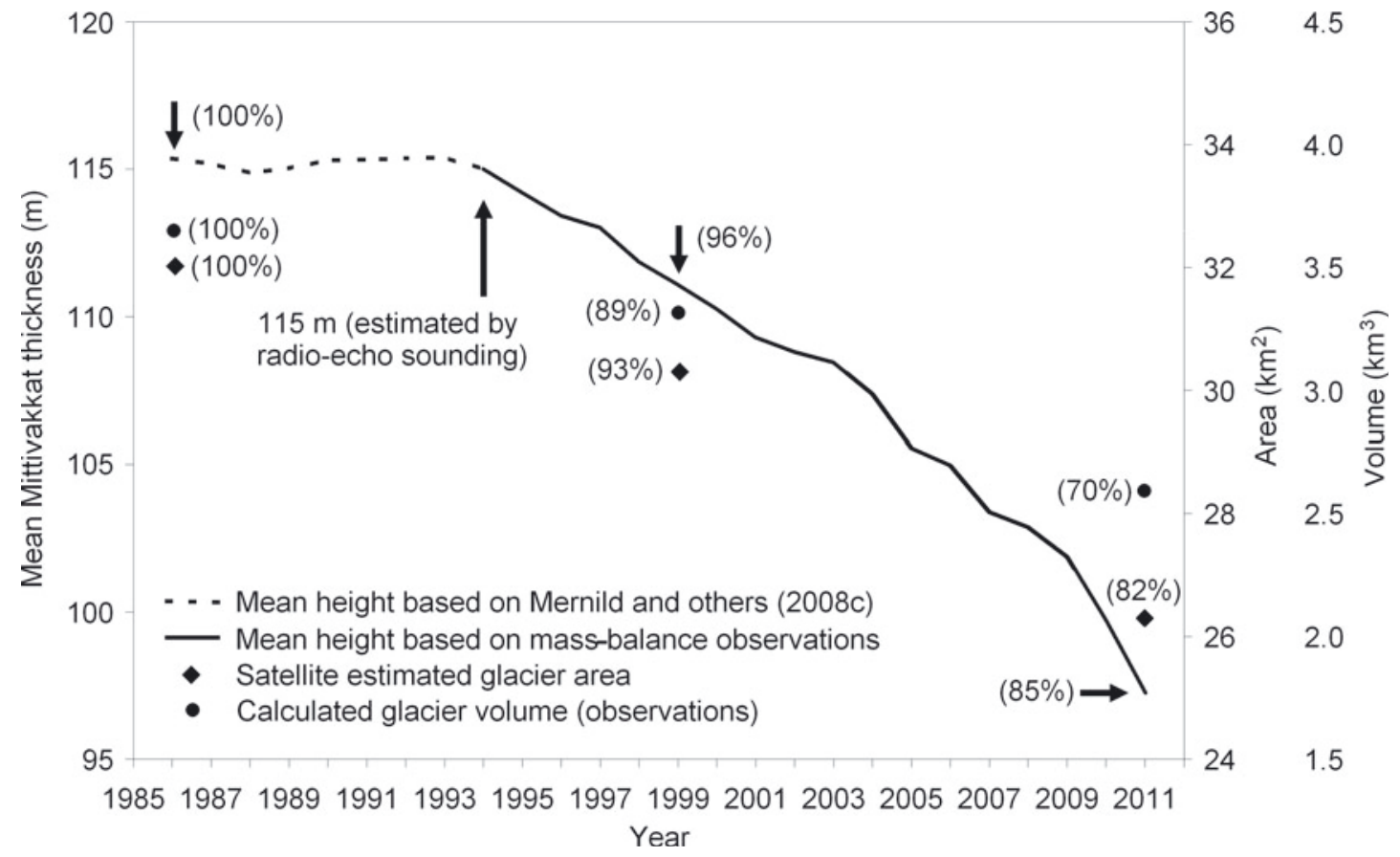

Fig. 4. Time series of estimated mean thickness (line), area (diamonds; Mernild and others, 2012) and volume (circles) for MG. The dashed time series is estimated based on MG net mass-balance calculations (Mernild and others, 2008c). The percent of 1986 MG mean height, area and volume (the 1986 values were set to $100 \%$ ) are shown in parentheses.

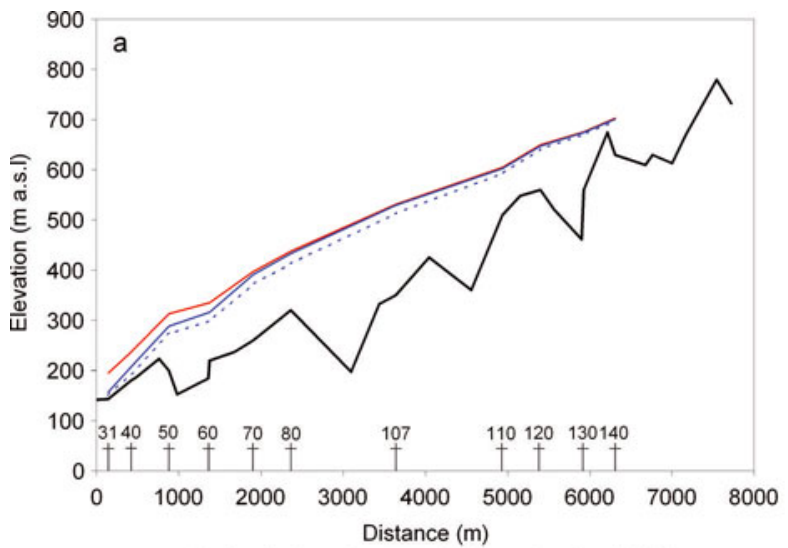

- Bedrock elevation - Surface elevation (1994)

- Surface elevation (2011) (based on SMB and We)

...... Surface elevation (2011) (based on SMB only)

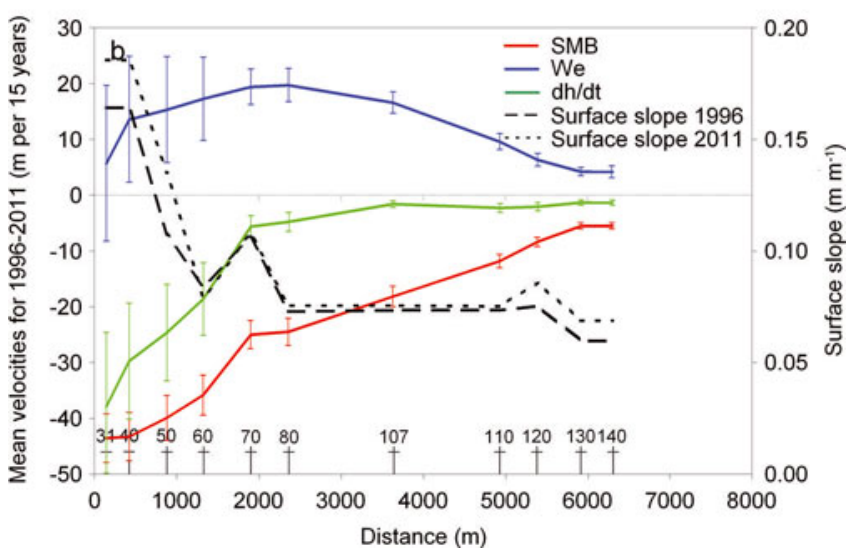

Fig. 5. (a) Longitudinal surface elevation for 1994 and 2011, where the 2011 elevation was calculated with and without vertical velocity $\left(w_{\mathrm{e}}\right)$, showing the positions of stakes $31-140$; and (b) longitudinal mean surface slope for 1996 and 2011, SMB, we and $\mathrm{d} h / \mathrm{d} t$ including uncertainty bars. largest changes $\left(-0.20 \mathrm{~m}\right.$ w.e. $\left.\mathrm{a}^{-2}\right)$ occurred along the center line of the glacier and at higher elevations, most pronounced at $\sim 500 \mathrm{~m}$ a.s.l., where significant trends below $-0.07 \mathrm{~m}$ w.e. $\mathrm{a}^{-2}$ occurred (Fig. 3a).

The summer balance shows more ablation at low elevations, and decreasing mass loss towards higher elevations (Fig. 3b), as expected. The summer mass balance varied from $-3.6 \mathrm{~m}$ w.e. $\mathrm{a}^{-1}$ at low elevations to $-1.4 \mathrm{~m}$ w.e. $\mathrm{a}^{-1}$ at high elevations, giving a mean gradient of $0.3 \mathrm{~m}$ w.e. $\mathrm{a}^{-1}$ per $100 \mathrm{~m}$ increase in elevation (1995/962007/08). Figure $3 \mathrm{~b}$ illustrates the spatial distribution of the annual change in summer balance, showing the largest change towards the margins, and most pronounced in the southern part of the glacier $\left(-0.22\right.$ m w.e. $\left.\mathrm{a}^{-2}\right)$. Significant trends occurred where the annual trend in summer balance was less than $-0.06 \mathrm{~m}$ w.e. $\mathrm{a}^{-2}$ (Fig. 3b). A possible explanation for the spatial pattern in summer mass-balance change is that the surface albedo was reduced as the margins receded, for example due to aeolian- and englacially transported debris exposed at the ice surface. Additionally, enhanced melting along the margins may have been due to increasing convection of heat from the surrounding areas. Towards the center of the glacier the energy balance will be less affected by these processes.

The net mass balance shows the combined effects of changes in winter and summer balances. The net mass balance shows the lowest values at low elevations $\left(-3.0 \mathrm{~m}\right.$ w.e. $\left.\mathrm{a}^{-1}\right)$ and highest values at higher elevations $\left(-0.4 \mathrm{~m}\right.$ w.e. $\left.\mathrm{a}^{-1}\right)$ (Fig. 3c). The mean net mass-balance gradient was $0.5 \mathrm{~m}$ w.e. $\mathrm{a}^{-1}$ per $100 \mathrm{~m}(1995 / 96-2010 / 11)$. The annual change in net mass balance is inhomogeneous, with the largest changes in the marginal area in the south $\left(-0.24 \mathrm{mw} \cdot \mathrm{e} \cdot \mathrm{a}^{-2}\right)$ and along the center line (around $-0.16 \mathrm{mw}$ we. $\mathrm{a}^{-2}$ ) (Fig. 3c). A significant trend occurred below $-0.08 \mathrm{~m}$ w.e. $\mathrm{a}^{-2}$. The mass loss at $\sim 500 \mathrm{~m}$ a.s.l. likely reflects that more ice has recently been exposed in that area 
as the snow and firn cover receded up-glacier. Due to the increased ice exposure, a change in surface albedo has occurred from $0.8-0.9$ for snow to around 0.4 for bare ice, highly reinforcing the surface melt of $M G$, especially at midto high elevations.

Surface elevation and ice thickness decreased across the glacier from 1995 to 2011 (Fig. 5a and b). Surface elevation changes $(\mathrm{d} h / \mathrm{d} t$ calculated from Eqn (2)) for the longitudinal MG profile are $-5.7 \pm 2.0$ to $-37.9 \pm 13.3 \mathrm{~m}$ w.e. (averaging $-23.3 \pm 8.2 \mathrm{~m}$ w.e.) on the lower part of the glacier at stakes $31,40,50,60$ and 70 , and $-1.4 \pm 0.5$ to $-2.3 \pm 0.8 \mathrm{~m}$ w.e. (averaging $-1.8 \pm 0.6 \mathrm{~m}$ w.e.) on the upper part at stakes 110 , 120, 130 and 140 (Fig. 5b, green line). The surface elevation change due to $\mathrm{SMB}$ alone was more negative than the total elevation changes: $-25.0 \pm 2.5$ to $-43.5 \pm 4.4 \mathrm{~m}$ w.e. (averaging $-37.5 \pm 3.8 \mathrm{~m}$ w.e.) in the lower part and $-5.5 \pm 0.6$ to $-11.8 \pm 1.2 \mathrm{~m}$ w.e. (averaging $-7.8 \pm 0.8 \mathrm{~m}$ w.e.) in the upper part (Fig. 5b, red line). Vertical strain was able to compensate for $\sim 60 \%$ of the elevation change due to SMB in the lower part, $\sim 25 \%$ in the upper part, and overall on average $\sim 50 \%$ for the longitudinal profile. If the glacier were in equilibrium with climate, vertical strain would be equal, and of opposite sign, to SMB; the large discrepancy in the magnitudes of the two processes is an indicator of the disequilibrium of MG. The vertical strain was unevenly distributed along the longitudinal profile (Fig. 5b, blue line), with the greatest compensation of thinning due to SMB at central elevations at stake $80\left(w_{\mathrm{e}}=20 \mathrm{~m}\right)$ where the mean surface velocity was greatest, and decreasing towards high and low elevations. That vertical strain is strongly positive throughout the region profiled suggests that the accumulation zone must be thinning strongly because the accumulation rates there are low and unlikely to be able to compensate for the transfer of mass to the ablation zone. Due to logistical constraints with working in the accumulation zone, we are unable to measure thinning there, but we are able to document thinning (elevation lowering) at a single point at the upper part of MG (Fig. 6; the nunatak location is illustrated in Fig. 1). Based on repeated markings of the ice margin position, the surface lowered $24 \mathrm{~m}$ between 1994 and 2010 at this specific location.

\section{Volume changes}

The glacier-covered area is one of the easiest glacier morphometric quantities to measure (e.g. Bahr, 2011). The surface area of MG was estimated for the years 1986, 1999 and 2011 based on satellite imagery, and the area changed by $-18 \%$ during this period (Mernild and others 2012). For the same period, the estimated mean ice thickness changed by $-15 \%$, from $115 \pm 17 \mathrm{~m}$ (1986) to $110 \pm 17 \mathrm{~m}$ (1999) to $97 \pm 15 \mathrm{~m}$ (2011) (where the uncertainties are assumed equal to the mass-balance method uncertainty of $\pm 15 \%$ ). Based on observed changes in area cover and mean thickness, the mean volume diminished by $1.1 \mathrm{~km}^{3}(30 \%)$ (Fig. 4), from $3.7 \pm 0.5 \mathrm{~km}^{3}$ (1986) to $3.3 \pm 0.5 \mathrm{~km}^{3}$ (1999) to $2.6 \pm 0.4 \mathrm{~km}^{3}$ (2011). This change in volume occurred contemporaneously with highly significant observed changes in mean annual air temperature (MAAT) of $0.09^{\circ} \mathrm{Ca}^{-1}\left(r^{2}=0.51 ; p<0.01\right)$, mean summer air temperature (June-August) of $0.09^{\circ} \mathrm{Ca}^{-1}\left(r^{2}=0.60 ; p<0.01\right)$ and in mean annual (uncorrected) precipitation of $-8 \mathrm{~mm}$ w.e. $\mathrm{a}^{-2}$ $\left(r^{2}=0.08 ; p<0.10\right)(1986-2011)$ at the nearby DMl station in Tasiilaq (Carstensen and Jørgensen, 2011). Climate records from other meteorological stations in southeast

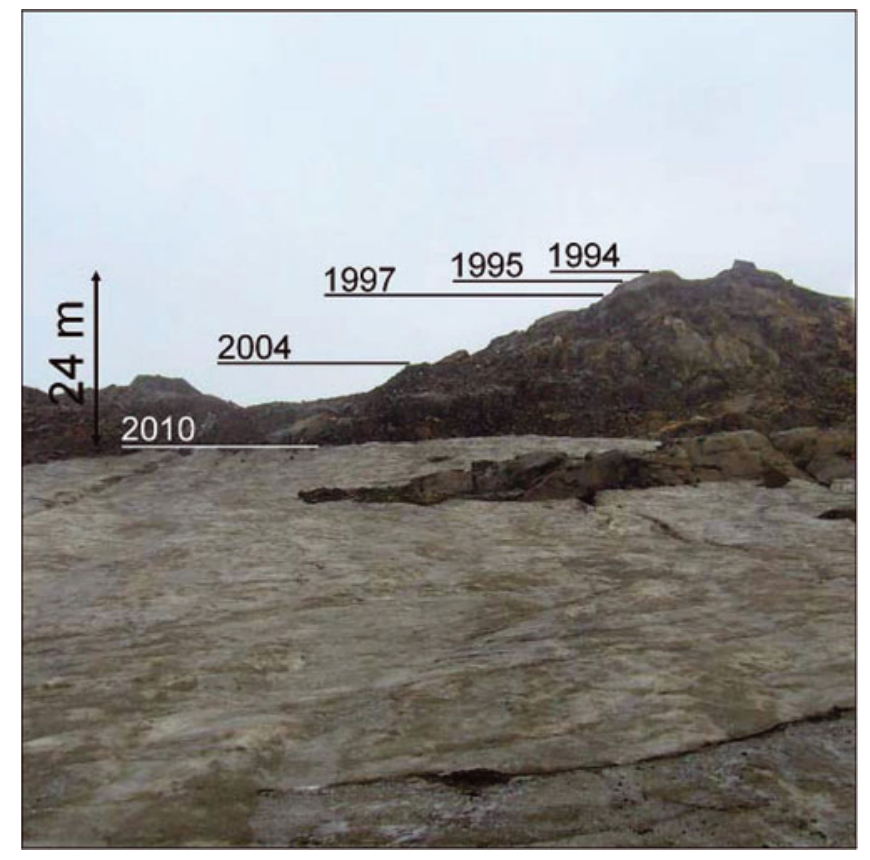

Fig. 6. Observed surface elevation lowering from 1994 through 2010 at a nunatak in the upper part of MG (the location of the nunatak, close to the northwestern margin, is marked with a black square in Fig. 1). The lines corresponding to the MG margin location were marked with spray-paint on the nunatak during the indicated summers. The photograph was taken looking south, and the distance from where the photo was taken to the glacier margin (the 2010 line) was approximately 12-13 m (photographs: S.H. Mernild, August 2010).

Greenland show significant increases in MAAT and mean summer air temperature since the early 1980s in the ranges $0.05-0.08^{\circ} \mathrm{Ca}^{-1}$ and $0.02-0.08^{\circ} \mathrm{Ca}^{-1}$, respectively, suggesting that the MG trends are not merely a local phenomenon but are indicative of glacier changes in the broader region (Mernild and others, 2011a). Such changes at the broader regional scale have been illustrated by Bjørk and others (2012), highlighting widespread retreat along the southeastern margin of Greenland over the past 80 years, where major retreat occurred not only during the recent warming, but also during and after warming in the early 20th century.

\section{Surface velocity changes}

The surface velocity of MG has been observed since 1996/97 at the stake locations (Fig. 1). Mean surface velocity has a maximum of $22 \mathrm{~m} \mathrm{a}^{-1}$ near the center of the glacier (shown in red in Fig. 7a), and a spatial average of $8 \mathrm{ma}^{-1}$. The velocity at the lateral margins consistent with drag from the valley walls and thinner ice (e.g. Cuffey and Paterson, 2010) was $\sim 3-5 \mathrm{~m} \mathrm{a}^{-1}$. The highest surface velocities are observed where the ice is thickest, and at the two cirques to the south of MG. In this context it has to be emphasized that the estimation of the spatial surface velocity field is likely to have a higher degree of uncertainty towards the crevassed parts of the glacier where no direct measurements of velocity are available.

Over the 15 year period (1996/97-2010/11), surface velocity has decelerated across the glacier, by $>50 \%$ in much of the ablation area. However, the change in annual surface velocity has been unevenly distributed across the glacier (Fig. 7b). The greatest deceleration, $\sim 0.6 \mathrm{~m} \mathrm{a}^{-2}$, is observed on the lower part of the glacier near the margins (a significant 

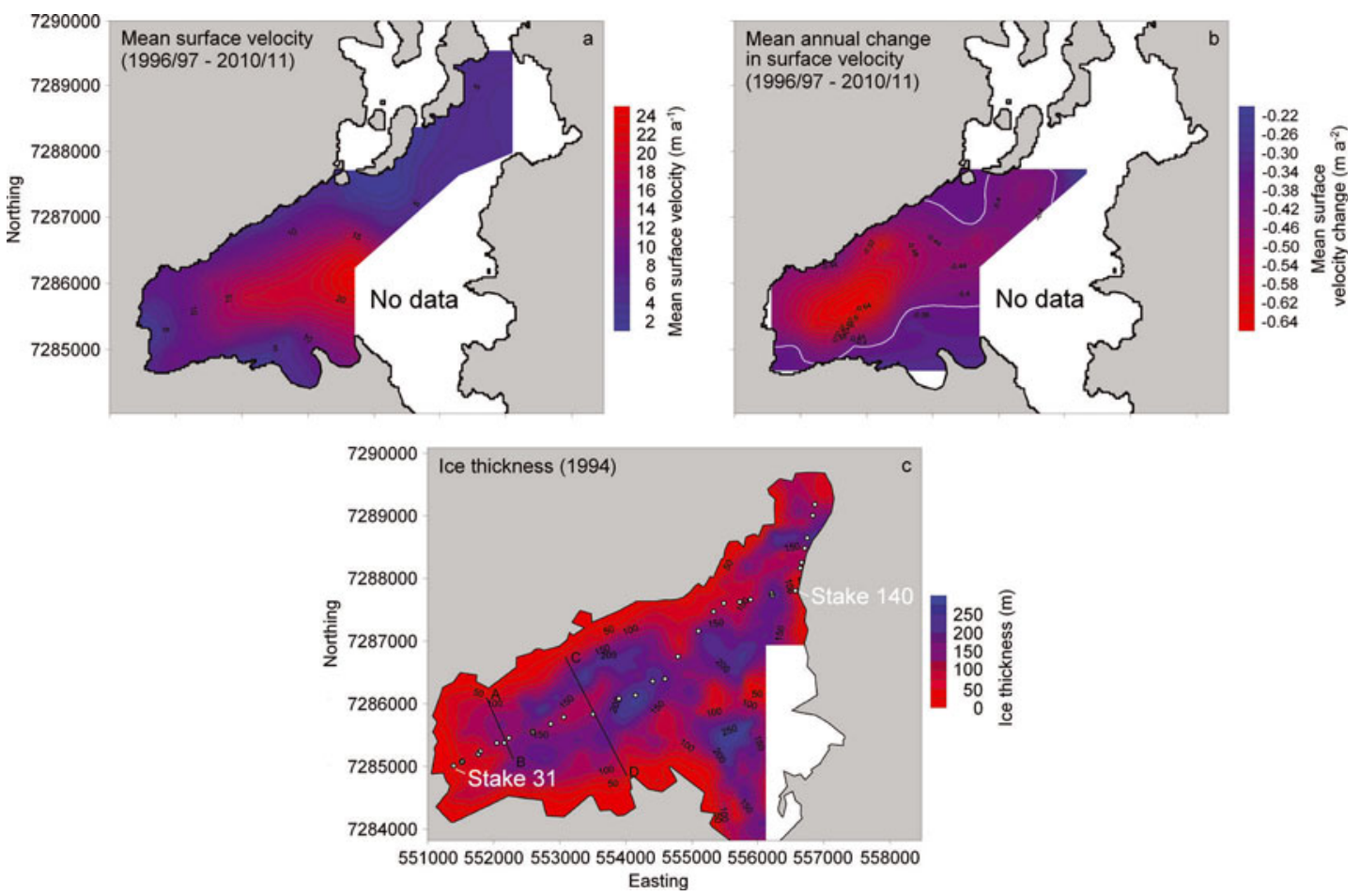

Fig. 7. Mittivakkat Gletscher: (a, b) Mean annual surface velocity (a) and mean surface velocity change (b) from 1996/97 to 2010/11. The white bold lines indicate the margin for significant annual trends in surface velocity, where values below are significant. (c) Ice thickness based on radar observations in 1994 (Knudsen and Hasholt, 1999) including the location of the longitudinal profile (white circles) (illustrated in $(a, b))$ and the two cross-section profiles (illustrated in Fig. 2). The locations of stakes 31 and 140 are marked. No observations were made in the southeastern part of the glacier since this is a heavily crevassed area. The white area has no data, and the margin in (a) and (b) is based on Landsat 7 ETM+ Mosaic imagery 1 August 2009 and 14 August 2011, and in (c) is derived from GPS observations.

deceleration trend occurred below $0.38 \mathrm{ma}^{-2}$; Fig. 7b), where the greatest thinning has also occurred (Fig. 3c).

The decelerating change in annual surface velocity observed across MG is likely related to the glacier thinning, which will decrease both deformation and sliding (Cuffey

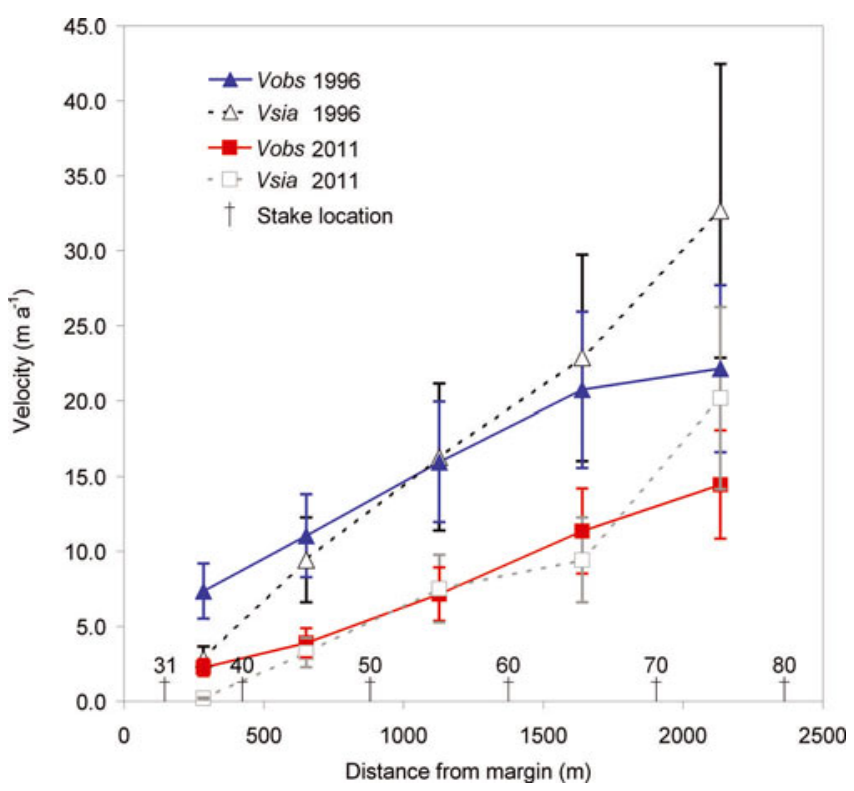

Fig. 8. Observed $\left(V_{\text {obs }}\right)$ and calculated $\left(V_{\text {sia; }}\right.$ Eqn (4)) surface velocities including uncertainty bars for 1996 and 2011 along a longitudinal profile (Fig. 7c) through the ablation zone. Each point is midway between two stake locations which are identified by dagger symbols. and Paterson, 2010), and slow the transfer of ice to lower elevations, which might buffer the retreat to some extent. An alternative explanation for the reduction in velocity is that changes in subglacial hydrology from increased surface melting over the study period have led to an earlier and more extensive development of channelized drainage and subsequent decrease in sliding each summer (e.g. Schoof, 2010; Sundal and others, 2011).

We assess the deceleration in the theoretical surface velocity that can be explained by changes in thickness, though the calculation of $v_{\text {sia }}$ (Eqn (4)) has a high degree of uncertainty due to uncertainty in the flow rate factor and the lack of higher-order stresses. The calculations indicate that the observed changes in surface velocity can largely be explained by the thickness changes over the study period (Fig. 8). Our calculation of $v_{\text {sia }}$ does not include a contribution to surface velocity from sliding, which is typically a large component on temperate glaciers (Weertman, 1957; Cuffey and Paterson, 2010). However, sliding velocity is commonly assumed to vary with ice thickness to a power of 1-3 (Bindschadler, 1983; Clarke, 2005; Cuffey and Paterson, 2010), and, allowing a component of surface velocity due to sliding (e.g. by lowering $A$ ) with powers that range from 1 to 3 , we find that the change in thickness can still explain most of the change in observed velocity without requiring changes in sliding related to hydrology since thickness changes affect sliding in a similar fashion to deformation.

The alternative hypothesis is that the observed surface velocity is due to a reduction in basal sliding associated with changing hydrology. Though meltwater draining to the beds of glaciers can increase sliding initially, once subglacial hydrologic systems adjust to the input, sliding can decrease 


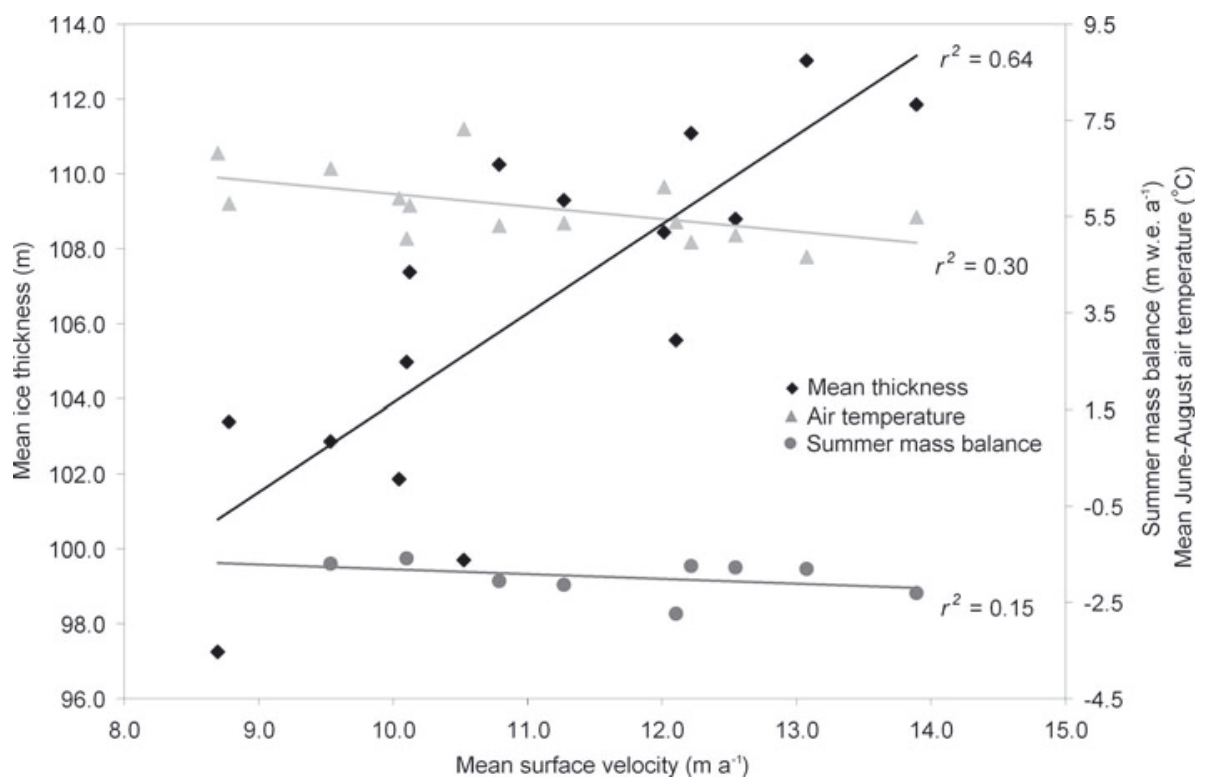

Fig. 9. Linear relationship between MG mean annual surface velocity and mean ice thickness (black diamonds) estimated from stake observations, observed summer mass balance (dark gray circles) and observed mean JJA air temperature at station Nunatak (light-gray triangles) from 1996 to 2011.

with sustained meltwater input (Bartholomaus and others, 2008; Schoof, 2010), potentially leading to lower average summer velocity (Truffer and others, 2005; Vincent and others, 2009; Sundal and others, 2011). Summer mass balance (and by association, melt) has become increasingly negative across MG during the study period (Fig. 3b). However, changes in melt appear to have only a minor impact on surface velocity at the seasonal scale. Summer mass balance and mean June-August (JJA) temperatures, both proxies for melt, are only weakly correlated with mean annual surface velocity $\left(r^{2}=0.15\right.$, insignificant at $p<0.25$, and $r^{2}=0.30$, significant at $p<0.025$, respectively), while thickness is relatively strongly positively correlated with surface velocity $\left(r^{2}=0.64\right.$, significant at $p<0.01$; Fig. 9). Thus changes to summer melt are relatively unimportant, compared with thickness changes, for changes in velocity.

Based on these analyses, we conclude that the observed 15 year slowdown was caused by decreasing ice deformation (and possibly sliding) resulting from glacier thinning, whereas changes to hydrology during that time do not seem to be important. This is consistent with previous studies which found that time periods of decadal lengths are necessary to observe the dynamic effects of thinning. Vincent and others (2009) recorded 20 years of thickening and speed-up followed by 30 years of thinning and slowdown at Glacier d'Argentière, France. In contrast, Müller and Iken (1973) found small ( 1 m) thickness changes inadequate to explain annual velocity changes over a 2-3 year period on White Glacier, Arctic Canada.

\section{Seasonal velocity variations}

Daily MG surface velocity was observed during two periods (May 2004 through July 2005, and March 2009 through August 2010) (Fig. 10a) (see Fig. 1 for locations of the GPS stations), illustrating variations in speed at short timescales. For the summer (JJA) the mean ice surface velocity varied between $0.061 \pm 0.01$ and $0.066 \pm 0.02 \mathrm{~m} \mathrm{~d}^{-1}$, with a maximum observed daily velocity of $0.10 \mathrm{~m} \mathrm{~d}^{-1}$ (26 June 2005).
For the winter (September-May) the velocity varied between $0.038 \pm 0.01$ and $0.043 \pm 0.01 \mathrm{~m} \mathrm{~d}^{-1}$. The summer values are $50-60 \%$ higher than the winter background values, and up to $160 \%$ higher for peak events (Fig. 10a and b). Similar seasonal patterns in ice surface velocity were observed at Flade Isblink ice cap (the largest ice cap in Greenland), northeast Greenland (Palmer and others, 2010), at John Evans Glacier, Nunavut, Canada (Bingham and others, 2003), and at the western land-terminating margin of the Greenland ice sheet, where the peak summer velocity was up to $220 \%$ above the winter background velocity (Bartholomew and others, 2010; Hoffman and others, 2011). There is some evidence that increases in water storage are associated with increases in sliding. MG peak velocity events were typically accompanied by uplift of a few centimeters. Similar uplift has been observed for mountain glaciers (e.g. Iken and others 1983; Bartholomaus and others, 2008; Howat and others, 2008) and the Greenland ice sheet (e.g. Bartholomew and others, 2010; Hoffman and others, 2011; Sole and others, 2011) during speed-up events.

The seasonal pattern in the daily surface velocity demonstrates the spring speed-up, which is common on temperate mountain glaciers, in which the onset of summer melt results in a large increase in velocity that is short-lived despite continued melt throughout the summer (e.g. Iken and others, 1983; Nienow and others, 1998; Anderson and others, 2004). At the beginning of each summer, velocity increase follows increasing air temperature, peaking in early to mid-June. After this initial speed-up, velocity has little clear relationship with air temperature until the end of summer when air temperatures fall to and remain well below $0^{\circ} \mathrm{C}$ (Fig. 10). This behavior is consistent with transient speed-up when subglacial water storage is increasing in spring and water inputs encounter an undeveloped drainage system (e.g. Truffer and others 2005; Bartholomaus and others 2008). The periods 25 July to 5 August 2004, 30 June to 19 July 2009, and 13 June to 18 July 2010 are examples of multi-week periods of increasing temperatures during midsummer accompanied 

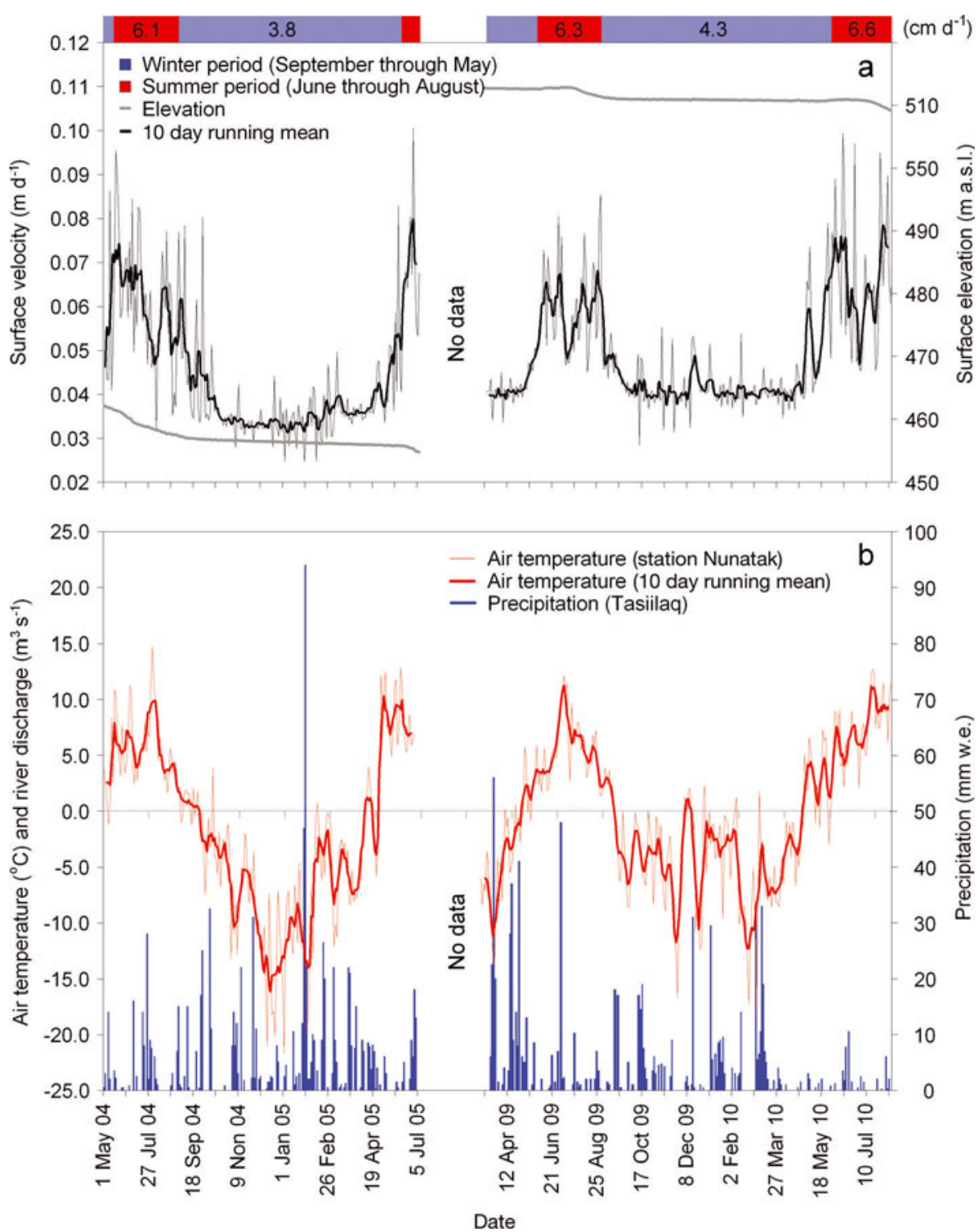

Fig. 10. (a) Observed MG seasonal surface velocity at the GPS station. Between 2005 and 2009 the GPS station was moved to a higher elevation on the glacier (see black and white diamonds in Fig. 1 for locations). The mean seasonal surface velocities are also shown, for the winter (September-May; marked with light blue at the top of the figure) and summer (June-August; marked with red). (b) Observed air temperature at station Nunatak and observed precipitation (uncorrected) at station Tasiilaq.

by a slowdown in surface velocity (Fig. 10a), suggestive of the presence of an efficient subglacial hydrologic system by midsummer. Despite these complex variations in sliding during summer, changes to hydrology over the 15 year study period do not appear to be the primary cause of the observed long-term deceleration (Section 4.3).

\section{CONCLUSIONS}

Direct mass-balance observations from Greenland's peripheral glaciers are rare, and MG is the glacier in Greenland with the longest mass-balance observation time series. We have analyzed spatially distributed winter, summer and annual mass balances and ice surface velocities based on direct observations of MG, along with calculated mean ice thickness and volume changes. We have found unambiguous evidence of ice thinning and slowdown in a warming climate. From 1986 to 2011, surface elevation decreased across the glacier, and the vertical strain rate was able to compensate for $\sim 50 \%$ of the elevation changes due to SMB.
We found significant changes in mean ice thickness $(-15 \%)$, ice volume $(-30 \%)$ and mean annual surface velocity $(-30 \%)$. The decrease in surface velocity was likely a dynamic effect of ice thinning. At the seasonal scale, daily summer surface velocities were $50-60 \%$ higher than the winter background values, and up to $160 \%$ higher for peak events. The specificity of the MG observations, as presented here, will be crucial for a detailed understanding of the behavior of Greenland's peripheral glaciers, which according to Bjørk and others (2012) and Mernild and others (2012) have exhibited widespread retreat along the southeastern margin of Greenland over the past few decades.

\section{ACKNOWLEDGEMENTS}

We extend a very special thanks to two anonymous reviewers and Mauri Pelto for insightful critique of this paper. This work was partly supported by the Climate Change Prediction Program and by the Scientific Discovery for Advanced Computing (SciDAC) program within the US Department of 
Energy's Office of Science and by a Los Alamos National Laboratory (LANL) Director's Fellowship. LANL is operated under the auspices of the National Nuclear Security Administration of the US Department of Energy under contract No. DE-AC52-06NA25396), and partly from the European Community's Seventh Framework Programme under grant agreement No. 262693. We thank the Danish Meteorological Institute for providing World Meteorological Organization synoptic meteorological data from Tasiilaq. N.T.K., S.H.M. and J.C.Y. did the MG mass-balance observations. S.H.M., N.T.K. and M.J.H. planned the study and analyzed the data, S.H.M., M.J.H., N.T.K. and J.C.Y. wrote the manuscript, and J.K.M., W.H.L., E.H. and R.S.F. contributed to the discussion of results and writing of the text.

\section{REFERENCES}

Anderson RS and 6 others (2004) Strong feedbacks between hydrology and sliding of a small alpine glacier. J. Geophys. Res., 109(F3), F03005 (doi: 10.1029/2004JF000120)

Bahr DB (2011) Estimation of glacier volume and volume change by scaling methods. In Singh VP, Singh P and Haritashya UK eds. Encyclopedia of snow, ice and glaciers. Springer, Dordrecht

Bartholomaus TC, Anderson RS and Anderson SP (2008) Response of glacier basal motion to transient water storage. Nature Geosci., 1(1), 33-37 (doi: 10.1038/ngeo.2007.52)

Bartholomew I, Nienow P, Mair D, Hubbard A, King MA and Sole A (2010) Seasonal evolution of subglacial drainage and acceleration in a Greenland outlet glacier. Nature Geosci., 3(6), 408-411 (doi: 10.1038/ngeo863)

Bindschadler R (1983) The importance of pressurized subglacial water in separation and sliding at the glacier bed. J. Glaciol., 29(101), 3-19

Bingham RG, Nienow PW and Sharp MJ (2003) Intra-annual and intra-seasonal flow dynamics of a High Arctic polythermal valley glacier. Ann. Glaciol., 37, 181-188 (doi: 10.3189/ 172756403781815762)

Bjørk AA and 8 others (2012) An aerial view of 80 years of climaterelated glacier fluctuations in southeast Greenland. Nature Geosci., 5(6), 427-432 (doi: 10.1038/ngeo1481)

Born EW and Böcher J (2001) The ecology of Greenland. Ministry of Environment and Natural Resources, Greenland, Nuuk

Carstensen LS and Jørgensen BV (2011) Weather and climate data from Greenland 1958-2010. (DMI Tech. Rep. 11-10) Danish Meterological Institute, Copenhagen

Clarke GKC (2005) Subglacial processes. Annu. Rev. Earth Planet. Sci., 33, 247-276 (doi: 10.1146/annurev.earth.33.092203. 122621)

Cogley JG (2012) The future of the world's glaciers. In HendersonSellers A and MacGuffie K eds. The future of the world's climate. Elsevier, Waltham, MA, 197-222

Cogley JG and Adams WP (1998) Mass balance of glaciers other than the ice sheets. J. Glaciol., 44(147), 315-325

Cuffey KM and Paterson WSB (2010) The physics of glaciers, 4th edn. Butterworth-Heinemann, Oxford

Hanna E and 8 others (2008) Increased runoff from melt from the Greenland Ice Sheet: a response to global warming. J. Climate, 21(2), 331-341

Hanna E and 6 others (2012a) The influence of North Atlantic atmospheric and oceanic forcing effects on 1900-2010 Greenland summer climate and ice melt/runoff. Int. J. Climatol., 33(4), 862-880 (doi: 10.1002/joc.3475)

Hanna E, Mernild SH, Cappelen J and Steffen K (2012b) Recent warming in Greenland in a long-term instrumental (1881-2012) climatic context: I. Evaluation of surface air temperature records. Environ. Res. Lett., 7(4), 045404 (doi: 10.1088/1748-9326/7/4/ 045404)
Hoffman MJ, Catania GA, Neumann TA, Andrews LC and Rumrill JA (2011) Links between acceleration, melting, and supraglacial lake drainage of the western Greenland Ice Sheet. J. Geophys. Res., 116(F4), F04035 (doi: 10.1029/2010JF001934)

Howat IM, Tulaczyk S, Waddington E and Björnsson H (2008) Dynamic controls on glacier basal motion inferred from surface ice motion. J. Geophys. Res., 113(F3), F03015 (doi: 10.1029/ 2007JF000925)

Hutter K (1983) Theoretical glaciology; material science of ice and the mechanics of glaciers and ice sheets. D. Reidel, Dordrecht/ Terra Scientific, Tokyo

Iken A, Röthlisberger H, Flotron A and Haeberli W (1983) The uplift of Unteraargletscher at the beginning of the melt season - a consequence of water storage at the bed? J. Glaciol., 29(101), $28-47$

Jacob T, Wahr J, Pfeffer WT and Swenson S (2012) Recent contributions of glaciers and ice caps to sea level rise. Nature, 482(7386), 514-518 (doi: 10.1038/nature10847)

Kargel JS and 15 others (2012) Brief communication: Greenland's shrinking ice cover: 'fast times' but not that fast. Cryosphere, 6(3), 533-537 (doi: 10.5194/tc-6-533-2012)

Kaser G, Cogley JG, Dyurgerov MB, Meier MF and Ohmura A (2006) Mass balance of glaciers and ice caps: consensus estimates for 1961-2004. Geophys. Res. Lett., 33(19), L19501 (doi: 10.1029/2006GL027511)

Knudsen NT and Hasholt B (1999) Radio-echo sounding at the Mittivakkat Gletscher, southeast Greenland. Arct. Antarct. Alp. Res., 31(3), 321-328

Knudsen NT and Hasholt B (2004) Mass balance observations at Mittivakkat Gletscher, Southeast Greenland 1995-2002. Nord. Hydrol., 35(4), 381-390

Knudsen NT, Nønberg P, Yde JC, Hasholt B and Heinemeier J (2008) Recent marginal changes of the Mittivakkat Glacier, Southeast Greenland and the discovery of remains of reindeer (Rangifer tarandus), polar bear (Ursus maritimus) and peaty material. Geogr. Tidsskr., 108(1), 137-142

Leclercq PW and Oerlemans J (2012) Global and hemispheric temperature reconstruction from glacier length fluctuations. Climate Dyn., 38(5-6), 1065-1079 (doi: 10.1007/s00382-0111145-7)

Marzeion B, Jarosch AH and Hofer M (2012) Past and future sealevel change from the surface mass balance of glaciers. Cryosphere, 6(6), 1295-1322 (doi: 10.5194/tc-6-1295-2012)

Meier MF and 7 others (2007) Glaciers dominate eustatic sea-level rise in the 21st century. Science, 317(5841), 1064-1067 (doi: 10.1126/science.1143906)

Mernild SH and Hasholt B (2006) Climatic control on river discharge simulations, Mittivakkat Glacier catchment, Ammassalik Island, SE Greenland. Nord. Hydrol., 37(4-5), 327-346 (doi: 10.2166/nh.2006.018)

Mernild SH and Hasholt B (2009) Observed runoff, jökulhlaups and suspended sediment load from the Greenland ice sheet at Kangerlussuaq, West Greenland, 2007 and 2008. J. Glaciol., 55(193), 855-858 (doi: 10.3189/002214309790152465)

Mernild SH and Liston GE (2012) Greenland freshwater runoff. Part II: distribution and trends 1960-2010. J. Climate, 25(17), 6015-6035 (doi: 10.1175/JCLI-D-11-00592.1)

Mernild SH, Liston GE, Hasholt B and Knudsen NT (2006) Snow distribution and melt modeling for Mittivakkat Glacier, Ammassalik Island, Southeast Greenland. J. Hydromet., 7(4), 808-824 (doi: 10.1175/JHM522.1)

Mernild SH, Hansen BU, Jakobsen BH and Hasholt B (2008a) Climatic conditions at the Mittivakkat Glacier catchment (19942006), Ammassalik Island, SE Greenland, and in a 109-year perspective (1898-2006). Geogr. Tidsskr., 108(1), 51-72

Mernild SH, Liston GE, Kane DL, Hasholt B and Knudsen NT (2008b) Spatial snow distribution, runoff, and mass balance modelling for entire Mittivakkat Glacier (1998-2006), Ammassalik Island, SE Greenland. Geogr. Tidsskr., 108(1), 121-136 (doi: 10.1080/00167223.2008.10649578) 
Mernild SH, Kane DL, Hansen BU, Jakobsen BH, Hasholt B and Knudsen NT (2008c) Climate, glacier mass balance and runoff (1993-2005) for the Mittivakkat Glacier catchment, Ammassalik Island, SE Greenland, and in a long term perspective (18981993). Hydrol. Res., 39(4), 239-256 (doi: 10.2166/nh.2008.101)

Mernild SH, Liston GE, Steffen K, Van den Broeke M and Hasholt B (2010) Runoff and mass-balance simulations from the Greenland Ice Sheet at Kangerlussuaq (Søndre Strømfjord) in a 30-year perspective, 1979-2008. Cryosphere, 4(2), 231-242 (doi: 10.5194/tc-4-231-2010)

Mernild SH and 6 others (2011a) Increasing mass loss from Greenland's Mittivakkat Gletscher. Cryosphere, 5(2), 341-348 (doi: 10.5194/tc-5-341-2011)

Mernild SH, Knudsen NT and Hanna E (2011b) Mittivakkat Gletscher, SE Greenland. In Richter-Menge J, Jeffries $\mathrm{MO}$ and Overland JE eds. Actic Report Card. (NOAA Report 2011) National Oceanic and Atmospheric Administration, Washington, DC http://www.arctic.noaa.gov/report11

Mernild SH, Malmros JK, Yde JC and Knudsen NT (2012) Multidecadal marine- and land-terminating glacier recession in the Ammassalik region, southeast Greenland. Cryosphere, 6(3), 625-639 (doi: 10.5194/tc-6-625-2012)

Mernild SH, Pelto MS, Malmros JK, Yde JC, Knudsen NT and Hanna E (2013) Identification of ablation rate, ELA, AAR and net mass balance using transient snowline variations on two Arctic glaciers. J. Glaciol., 59(216), 649-659

Müller F and Iken A (1973) Velocity fluctuations and water regime of Arctic valley glaciers. IASH Publ. 95 (Symposium at Cambridge 1969 - Hydrology of Glaciers), 165-182

Nienow P, Sharp M and Willis I (1998) Seasonal changes in the morphology of the subglacial drainage system, Haut Glacier d'Arolla, Switzerland. Earth Surf. Process. Landf., 23(9), 825843 (doi: 10.1002/(SICI)1096-9837(199809)23:9<825::AIDESP893>3.0.CO;2-2)

Oerlemans J, Dyurgerov M and Van de Wal RSW (2007) Reconstructing the glacier contribution to sea-level rise back to 1850. Cryosphere, 1(1), 59-65 (doi: 10.5194/tc-1-59-2007)

Østrem G and Brugman M (1991) Glacier mass-balance measurements: a manual for field and office work. (NHRI Science Report 4) Environment Canada. National Hydrology Research Institute, Saskatoon, Sask.

Østrem G and Stanley AD (1969) Glacier mass balance measurements, a manual for field and office work: a guide for personnel with limited backgrounds in glaciology. Department of the Environment, Inland Waters Branch, Ottawa, Ont.

Palmer SJ, Shepherd A, Sundal A, Rinne E and Nienow P (2010) InSAR observations of ice elevation and velocity fluctuations at the Flade Isblink ice cap, eastern North Greenland. J. Geophys. Res., 15(F4), F04037 (doi: 10.1029/2010JF001686)

Rastner P, Bolch T, Mölg N, Machguth H, Le Bris R and Paul F (2012) The first complete inventory of the local glaciers and ice caps on Greenland. Cryosphere, 6(6), 1483-1495 (doi: 10.5194/ tc-6-1483-2012)

Schoof C (2010) Ice-sheet acceleration driven by melt supply variability. Nature, 468(7325), 803-806 (doi: 10.1038/nature09618)

Sole AJ and 6 others (2011) Seasonal speedup of a Greenland marine-terminating outlet glacier forced by surface meltinduced changes in subglacial hydrology. J. Geophys. Res. 116(F3), F03014 (doi: 10.1029/2010JF001948)

Sundal AV, Shepherd A, Nienow P, Hanna E, Palmer S and Huybrechts P (2011) Melt-induced speed-up of Greenland ice sheet offset by efficient subglacial drainage. Nature, 469(7331), 521-524 (doi: 10.1038/nature09740)

Truffer M, Harrison WD and March RS (2005) Correspondence. Record negative glacier balances and low velocities during the 2004 heatwave in Alaska, USA: implications for the interpretation of observations by Zwally and others in Greenland. J. Glaciol., 51(175), 663-664 (doi: 10.3189/ 172756505781829016)

Van de Wal RSW and 6 others (2008) Large and rapid melt-induced velocity changes in the ablation zone of the Greenland Ice Sheet. Science, 321(5885), 111-113 (doi: 10.1126/ science.1158540)

Vincent C, Soruco A, Six D and Le Meur E (2009) Glacier thickening and decay analysis from 50 years of glaciological observations performed on Glacier d'Argentière, Mont Blanc area, France. Ann. Glaciol., 50(50), 73-79 (doi: 10.3189/ 172756409787769500)

Weertman J (1957) On the sliding of glaciers. J. Glaciol., 3(21), 33-38

Yde JC and Knudsen NT (2007) 20th-century glacier fluctuations on Disko Island (Qeqertarsuaq), Greenland. Ann. Glaciol., 46, 209-214 (doi: 10.3189/172756407782871558)

MS received 23 January 2013 and accepted in revised form 13 April 2013 